\title{
ANALISIS PENDIDIKAN TERHADAP PAD (PENDAPATAN ASLI DAERAH) DI KABUPATEN LAMONGAN PERIODE TAHUN 2010 - 2014
}

\author{
*( Abid Muhtarom \\ Prodi Manajemen, Fakultas Ekonomi, Universitas Islam Lamongan \\ $\mathrm{Jl}$. Veteran No.53A Lamongan \\ Telp. ( 0322 ) 324706, Faks. ( 0322 ) 324706 \\ Email :jpim.unisla@gmail.com
}

\begin{abstract}
ABSTRAK
Pendidikan merupakan suatu faktor yang mempengaruhi output suatu daerah. Jumlah penduduk yang besar, khususnya penduduk dengan usia produktif, akan meningkatkan jumlah angkatan kerja yang tersedia. Jumlah tenaga kerja yang besar disertai dengan pendidikan yang memadai akan memacu PAD (Pendapatan Asli Daerah) yang tinggi.

Penelitan ini menggunakan penelitian eksplanatori, yaitu hasil yang diperoleh dalam penelitian ini diharapkan dapat memberikan penjelasan tentang bagaimana Analisis Pendidikan Terhadap PAD (PendapatanAsli Daerah) Kabupaten Lamongan (Husaini, 2008:5).

Dari hasil perhitungan didapatkan angka korelasi antara Pendidikan dengan Pendapatan Asli Daerah Kabupaten Lamongan sebesar -0,898. Artinya hubungan kedua variabel tersebut sangat kuat tetapi negatif. Korelasi negatif menunjukan bahwa hubungan antara Pendidikan dengan Pendapatan Asli Daerah Kabupaten Lamongan tidak searah atau berlawanan. Data dapat dilihat probalitas (sig) sebesar 0,019 yang lebih kecil dari 0,05, maka ada hubungan kedua variabel pendidikan dengan Pendapatan Asli Daerah Kabupaten Lamongan singnifikan. Permasalahanpermasalahan dikarenakan banyaknya pendidikan yang rendah yang ada di Kabupaten Lamongan sebagian besar tergolong sebagai unskilled labor atau tenaga kerja tidak terdidik.
\end{abstract}

Kata kunci : Pendidikan, Pendapatan Daerah dan Tenaga Kerja

\section{PENDAHULUAN}

Pendidikan merupakan suatu faktor yang mempengaruhi output suatu daerah. Jumlah penduduk yang besar, khususnya penduduk dengan usia produktif, akan meningkatkan jumlah angkatan kerja yang tersedia. Jumlah tenaga kerja yang besar disertai dengan pendidikan yang memadai akan memacu PAD (Pendapatan Asli Daerah) yang tinggi.
Tantangan utama pendidikan di Kabupaten Lamongan adalah bagaimana meningkatkan kualitas sumber daya manusia. Peningkatan kualitas sumber daya manusia adalah salah satu cara untuk meningkatkan produktivitas. Sekitar 55 persen dari tenaga kerja di Jawa Timur hanya mengecap pendidikan Sekolah Dasar. Hal ini juga ditunjukkan oleh angka partisipasi murni (APM) sekolah yang 
semakin menurun pada tingkat SMP dan SMA.

Hasil Survei BPS (Badan Pusat Statistik) kabupaten Lamongan yang dilaksanakan pada 2010 diketahui bahwa pendidikan di kabupaten Lamongan sebesar 796300 orang dan tahun 2011 naik sebesar $817 \quad 460$ orang. Sedangkan tahun 2012 turun sebesar 813568 orang dari pada tahun 2011, untuk tahun 2013 sebesar 818 216 orang naik dari pada tahun 2012 .

Sejalan dengan peningkatan jumlah pekerja tersebut, maka jumlah pengangguran mengalami penurunan sebesar 262,8 ribu orang (25,43 persen).Penyerapan tenaga kerja perempuan selama Agustus 2008 Agustus 2009, lebih besar dibandingkan dengan laki-laki, yaitu masing-masing jumlah pekerja perempuan meningkat 228,6 ribu orang dan pekerja laki-laki meningkat sebesar 194,2 ribu orang. Namun demikian, dominasi peningkatan penduduk perempuan yang bekerja umumnya hanya sebagai pekerja keluarga., sehingga peningkatan jumlah tenaga kerja tidak selalu memberikan implikasi yang positif terhadap peningkatan pendapatan pekerja, karena penambahan jumlah tenaga kerja hanya terserap sebagai pekerja keluarga atau membantu rumahtangga/suami dalam melakukan kegiatan ekonomi yang sifatnya informal. Lebih lanjut, jika melihat status pekerjaan berdasarkan klasifikasi formal dan informal, maka pada Agustus 2009 sekitar 73,12 persen tenaga kerja bekerja pada kegiatan informal (Pemprov jatim, 2010).
Permasalahan-permasalahan seperti tersebut di atas dikarenakan banyaknya pendidikan yang rendah yang ada di Kabupaten Lamongan sebagian besar tergolong sebagai unskilled labor atau tenaga kerja tidak terdidik. Tenaga kerja tidak terdidik adalah tenaga kerja kasar yang hanya mengandalkan tenaga saja. Contoh: kuli, buruh angkut, pembantu rumah tangga, dan sebagainya. Tingginya angka unskilled labor menunjukkan bahwa kualitas tenaga kerja di Jawa Timur masih rendah.

Berbagai upaya telah dilakukan oleh pemerintah Daerah Kabupaten Lamongan untuk bisa meningkatkan pendidikan di kabupaten Lamongan. Namun demikian menarik untuk diteliti apakah pendidikan di Kabupaten Lamongan berdampak terhadap Pendapatan Asli Daerah, Mengingat tingginya jumlah tenaga kerja yang terserap lebih banyak pada sektor informal. Sektor informal memang menawarkan peluang kerja yang lebih fleksibel dalam hal persyaratan namun lemah dalam hal jaminan keberlangsungan pekerjaan tersebut (job security). Pekerja sektor informal rentan terhadap gejolak ekonomi dan cenderung tidak menentu penghasilannya khususnya para pekerja bebas (pekerja tidak tetap) yang hanya bekerja sesekali saja dan berpindah-pindah majikan maupun jenis pekerjaannya. Pekerja sektor informal juga umumnya tidak dilindungi oleh fasilitas kesehatan, perlindungan kecelakaan, maupun jaminan pensiun. 
LANDASAN TEORI

\section{Pendidikan}

Pendidikan

adalah

pembelajaran

pengetahuan,

keterampilan, dan kebiasaan sekelompok orang yang diturunkan dari satu generasi ke generasi berikutnya melalui pengajaran, pelatihan, atau penelitian. Pendidikan sering terjadi di bawah bimbingan orang lain, tetapi juga memungkinkan secara otodidak. Setiap pengalaman yang memiliki efek formatif pada cara orang berpikir, merasa, atau tindakan dapat dianggap pendidikan. Pendidikan umumnya dibagi menjadi tahap seperti prasekolah, sekolah dasar, sekolah menengah dan kemudian perguruan tinggi, universitas atau magang.

Sebuah hak atas pendidikan telah diakui oleh beberapa pemerintah. Pada tingkat global, Pasal 13 PBB 1966 Kovenan Internasional tentang Hak Ekonomi, Sosial dan Budaya mengakui hak setiap orang atas pendidikan. Meskipun pendidikan adalah wajib di sebagian besar tempat sampai usia tertentu, bentuk pendidikan dengan hadir di sekolah sering tidak dilakukan, dan sebagian kecil orang tua memilih untuk pendidikan home-schooling, elearning atau yang serupa untuk anakanak mereka.

Pendidikan biasanya berawal saat seorang bayi itu dilahirkan dan berlangsung seumur hidup. Pendidikan bisa saja berawal dari sebelum bayi lahir seperti yang dilakukan oleh banyak orang dengan memainkan musik dan membaca kepada bayi dalam kandungan dengan harapan ia bisa mengajar bayi mereka sebelum kelahiran.

Bagi sebagian orang, pengalaman kehidupan sehari-hari lebih berarti daripada pendidikan formal. Seperti kata Mark Twain, "Saya tidak pernah membiarkan sekolah mengganggu pendidikan saya."

Anggota keluarga mempunyai peran pengajaran yang amat mendalam, sering kali lebih mendalam dari yang disadari mereka, walaupun pengajaran anggota keluarga berjalan secara tidak resmi.

Telah dikemukakan bahwa tingkat pendidikan yang tinggi sangat penting bagi negara-negara untuk dapat mencapai tingkat pertumbuhan ekonomi yang tinggi. Analisis empiris cenderung mendukung prediksi teoritis bahwa negara-negara miskin harus tumbuh lebih cepat dari negaranegara kaya karena mereka dapat mengadopsi teknologi yang sudah dicoba dan diuji oleh negara-negara kaya. Namun, transfer teknologi memerlukan manajer berpengetahuan dan insinyur yang mampu mengoperasikan mesin-mesin baru atau praktek produksi yang dipinjam dari pemimpin dalam rangka untuk menutup kesenjangan melalui peniruan. Oleh karena itu, kemampuan suatu negara untuk belajar dari pemimpin adalah fungsi dari efek "human capital". Studi terbaru dari faktor-faktor penentu pertumbuhan ekonomi agregat telah menekankan pentingnya lembaga ekonomi fundamental dan peran keterampilan kognitif. 
Pada tingkat individu, ada banyak literatur, umumnya terkait dengan karya Jacob Mincer,tentang bagaimana laba berkaitan dengan pendidikan dan modal manusia lainnya. Karya ini telah memotivasi sejumlah besar studi, tetapi juga kontroversial. Kontroversi utama berkisar bagaimana menafsirkan dampak sekolah. Beberapa siswa yang telah menunjukkan potensi yang tinggi untuk belajar, dengan menguji dengan intelligence quotient yang tinggi, mungkin tidak mencapai potensi penuh akademis mereka, karena kesulitan keuangan.

Ekonom Samuel Bowles dan Herbert Gintis berpendapat pada tahun 1976 bahwa ada konflik mendasar dalam pendidikan Amerika antara tujuan egaliter partisipasi demokratis dan ketidaksetaraan tersirat oleh profitabilitas terus dari produksi kapitalis di sisi lain.

Melek aksara (juga disebut dengan melek huruf) adalah kemampuan membaca dan menulis. Lawan kata "melek aksara" adalah buta huruf atau tuna aksara, di mana ketidakmampuan membaca dan menulis ini masih menjadi masalah, terutama di negara-negara Asia Selatan, Timur Tengah, dan Afrika (40\% sampai $50 \%$ ). Asia Timur dan Amerika Selatan memiliki tingkat buta huruf sekitar $10 \%$ sampai $15 \%$. Biasanya, tingkat melek aksara dihitung dari persentase populasi dewasa yang mampu membaca dan menulis.

Melek aksara juga dapat diartikan sebagai kemampuan untuk menggunakan bahasa dan menggunakannya untuk mengerti sebuah bacaan, mendengarkan perkataan, mengungkapkannya dalam bentuk tulisan, dan berbicara. Dalam perkembangan modern kata ini lalu diartikan sebagai kemampuan untuk membaca dan menulis pada tingkat yang baik untuk berkomunikasi dengan orang lain, atau dalam taraf bahwa seseorang dapat menyampaikan idenya dalam masyarakat yang mampu baca-tulis, sehingga dapat menjadi bagian dari masyarakat tersebut.

Organisasi PBB untuk Pendidikan, Ilmu Pengetahuan dan Kebudayaan (UNESCO) memiliki definisi sebagai Kemampuan baca-tulis dianggap penting karena melibatkan pembelajaran berkelanjutan oleh seseorang sehingga orang tersebut dapat mencapai tujuannya, dimana hal ini berkaitan langsung bagaimana seseorang mendapatkan pengetahuan, menggali potensinya, dan berpartisipasi penuh dalam masyarakat yang lebih luas.

Banyak analis kebijakan menganggap angka melek aksara adalah tolak ukur penting dalam mempertimbangkan kemampuan sumber daya manusia di suatu daerah. Hal ini didasarkan pada pemikiran yang berdalih bahwa melatih orang yang mampu baca-tulis jauh lebih murah daripada melatih orang yang buta aksara, dan umumnya orangorang yang mampu baca-tulis memiliki status sosial ekonomi, kesehatan, dan prospek meraih peluang kerja yang lebih baik. 
Argumentasi para analis kebijakan ini juga menganggap kemampuan bacatulis juga berarti peningkatan peluang kerja dan akses yang lebih luas pada pendidikan yang lebih tinggi.

Sebagai contoh di Kerala, India, tingkat kematian wanita dan anakanak menurun drastis pada tahun 1960an, saat anak-anak gadis terdidik disaat reformasi pendidikan setelah tahun 1948 mulai berkeluarga. Walaupun begitu riset terbaru beragumentasi bahwa hasil yang didapat di atas mungkin lebih banyak disumbangkan sebagai hasil dari disekolahkannya anak-anak tersebut dibandingkan dari kemampuan bacatulisnya saja. Walaupun begitu, di seluruh dunia fokus dari sistem pendidikan tetap merupakan konsepkonsep yang meliputi komunikasi melalui teks dan media cetak, dan hal ini masih merupakan dasar dari definisi melek aksara.

\section{Pendapatan Asli Daerah}

Pendapatan Asli Daerah (PAD) adalah salah satu sumber penerimaan daerah yang mendukung kemampuan keuangan daerah. Pengertian Pendapatan Asli Daerah menurut Undang-Undang no.28 Tahun 2009 yaitu sumber keuangan daerah yang digali dari wilayah daerah yang bersangkutan yang terdiri dari hasil pajak daerah, hasil retribusi daerah, hasil pengelolaan kekayaan daerah yang dipisahkan dan lain-lain pendapatan asli daerah yang sah.

Menurut Nurcholis (2007 : 182) pendapatan asli daerah adalah pendapatan yang diperoleh daerah dari penerimaan pajak daerah, retribusi daerah, laba perusahaan daerah dan lain-lain yang sah. Pendapatan Daerah adalah semua hak daerah yang diakui sebagai penambah nilai kekayaan bersih dalam periode anggaran tertentu (UU No.32 Tahun 2004 tentang pemerintahan daerah), pendapatan daerah berasal dari dana perimbangan pusat dan daerah juga berasal dari daerah itu sendiri yakni pendapatan asli daerah serta lain-lain pendapatan yang sah.

Menurut Mardiasmo (2002: 132), Pendapatan Asli Daerah (PAD) adalah penerimaan daerah dari sektor pajak daerah, retribusi daerah, hasil perusahaan milik daerah, hasil pengelolaan kekayaan daerah yang dipisahkan, dan lain-lain Pendapatan Asli Daerah (PAD) yang sah. Kewenangan untuk memberdayakan sumber keuangan sendiri dilakukan dalam wadah Pendapatan Asli Daerah (PAD) yang sumber utamanya adalah pajak daerah dan retribusi daerah. Idealnya suatu perimbangan keuangan pusat dan daerah terjadi apabila setiap tingkat pemerintahan bebas dalam bidang keuangan untuk membiayai pelaksanaan tugas dan wewenang masing-masing. Artinya Pendapatan Asli Daerah (PAD) menjadi sumber pendapatan utama atau dominan, sementara subsidi atau transfer dari tingkat pemerintah pusat merupakan sumber penerimaan pendukung atau tambahan yang peranannya tidak dominan. Pendapatan Asli Daerah (PAD) merupakan salah satu sumber pembiayaan pemerintahan daerah yang peranannya sangat tergantung kemampuan dan kemauan daerah 
dalam menggali potensi yang ada di daerah.

Perimbangan keuangan pemerintah pusat dan daerah adalah sistem pembagian keuangan yang adil, proporsional, demokratis, transparan dan bertanggungjawab dalam rangka pendanaan penyelenggaraan desentralisasi, dengan mempertimbangkan potensi, kondisi dan kebutuhan daerah serta besaran penyelenggaraan dekonsentrasi dan tugas pembatuan (UU no.32 Tahun 2004).

Pendapatan Asli Daerah adalah penerimaan yang diperoleh dari sumber-sumber dalam wilayahnya sendiri yang dipungut berdasarkan peraturan daerah yang sesuai dengan peraturan perundang-undangan yang berlaku yang terdiri atas:

a) Hasil pajak daerah yaitu pungutan yang dilakukan oleh pemerintah daerah kepada semua objek pajak, seperti orang / badan, benda bergerak / tidak bergerak.

b) Hasil retribusi daerah, yaitu pungutan yang dilakukan sehubungan dengan suatu jasa/fasilitas yang berlaku oleh pemerintah daerah secara langsung dan nyata.

c) Hasil perusahaan milik daerah dan hasil pengelolaan kekayaan daerah yang dipisahkan antara lain laba dividen, penjualan saham milik daerah.

d) Lain-lain pendapatan asli daerah yang sah antara lain hasil penjualan aset tetap dan jasa giro (Sirozujilam dan Mahalli, 2011).

Pendapatan Asli Daerah (PAD) yang tinggi belum merupakan jaminan tingginya pendapatan masyarakat di suatu daerah (regional income). Namun demikian, tingginya PAD dapat menjadi sumberdaya yang sangat penting bagi pemerintah daerah di dalam pengembangan wilayah termasuk dalam peningkatan pendapatan masyarakatnya (Rustiadi, Ghifari, Suradinata, Wijanarko, Supranto, Karmaji, Oyong, Nurbaya dan Martha, 2010).

Perolehan PAD diperlukan manajemen pemanfaatan dana yang mampu digunakan semaksimal mungkin bagi kemakmuran masyarakat yang sebesar-besarnya melalui program-program dan kegiatan-kegiatan yang diluncurkan pemerintah daerah tersebut (Susanto, Ghifari, Suradinata, Wijanarko, Supranto, Karmaji, Oyong, Nurbaya dan Martha, 2010).

Adapun sumber-sumber pendapatan asli daerah menurut Undang-Undang RI No.32 Tahun 2004 yaitu :

1) PAD yang terdiri dari :

a. Hasil pajak daerah yaitu pungutan daerah menurut peraturan yang ditetapkan oleh daerah untuk pembiayaan rumah tangganya sebagai badan hukum publik. Pajak daerah sebagai pungutan yang dilakukan pemerintah daerah yang hasilnya digunakan untuk pengeluaran umum yang balas jasanya tidak langsung diberikan sedang pelaksanaanya bisa langsung dipaksakan.

b. Hasil retribusi daerah yaitu pungutan yang telah secara sah menjadi pungutan daerah sebagai pembayaran pemakaian atau karena memperoleh jasa pekerjaan, usaha atau milik pemerintah daerah yang 
$\begin{array}{llr}\text { bersangkutan. } & \text { Retribusi daerah } \\ \text { mempuyai } & \text { sifat-sifat } & \text { yaitu }\end{array}$ pelaksanaanya besrifat ekonomis, ada imbalan langsung walau harus memenuhi persyaratan-persyaratan formil maupun materiil, tetapi ada alternatif untuk mau tidak membayar, merupakan pungutan yang sifatnya budgetatinya tidak menonjol, dalam hal-hal tertentu retribusi daerah adalah pengembalian biaya yang telah dilakukan oleh pemerintah daerah untuk memenuhi permintaan anggota masyarakat.

c. Hasil perusahaan milik daerah dan hasil pengelolaan kekayaan daerah yang dipisahkan. Hasil perusahaan milik daerah merupakan pendapatan daerah dari keuntungan bersih perusahaan daerah yang berupa dana pembangunan daerah dan bagian untuk anggaran belanja daerah yang disetor ke kas daerah, baik perusahaan derah yang dipisahkan, sesuai dengan motif pendirian dan pengelolaan maka sifat perubahan daerah adalah suatu kesatuan produksi yang bersifat menambah pendapatan daerah, memberi jasa, menyelenggarakan kemanfaatan umum dan memperkembengkan perekonomian daerah.

d. Lain-lain pendapatan yang sah ialah pendapatan-pendapatan yang tidak termasuk dalam jenis-jenis pajak daerah, restibusi daerah, pendapatan dinas-dinas. Lain-lain usaha daerah yang sah mempunyai sifat pembuka bagi pemerintah daerah untuk melakukan kegiatan yang menghasilkan baik berupa materi dalam kegiatan tersebut bertujuan untuk menunjang, melapangkan, dan memantapkan suatu kebijakan daerah disuatu bidang tertentu.

2) Dana perimbangan diperoleh melalui bagian pendapatan daerah dari penerimaan pajak bumi dan bangunan dari pedesaan , perkotaan, pertambangan sumber daya alam, dan serta bea perolehan hak atas tanah dan bangunan. Dana perimbangan terdiri atas dana bagi hasil, dana alokasi umum, dan dana alokasi khusus.

3) Lain - lain pendapatan daerah yang sah adalah pendapatan derah dari sumber lain misalnya sumbangan pihak ketiga kepada daerah yang dilaksanakan sesuai dengan peraturan perundang-undangan yang berlaku.

Menurut Abdul Halim "Akuntansi Sektor Publik : akuntansi keuangan Daerah (2013 : 101) Pendapatan Asli Daerah (PAD) merupakan semua penerimaan daerah yang berasal dari sumber ekonomi asli daerah. KelompokpendapatanAsli Daerah dipisahkanmenjadi 4 jenispendapatan, yaitusebagaiberikut :

a) Pajak Daerah

b) Retribusi Daerah

c) HasilPengelolaankekayaanmilikda erah yang dipisahkan

d) Lain-lain PAD yang sah.

\section{METODELOGI PENELITIAN}

Penelitan ini menggunakan penelitian eksplanatori, yaitu hasil yang diperoleh dalam penelitian ini diharapkan dapat memberikan penjelasan tentang bagaimana Analisis Pendidikan TerhadapPAD (PendapatanAsli

Daerah) 
KabupatenLamongan

(Husaini, 2008:5).

Ditinjau dari sifat hubungan antara variabelnya, penelitian ini dirancang sebagai penelitian kausal dimana variabel yang satu dengan yang lain tidak sekedar dijelaskan hubungan korelasinya, lebih dari itu akan didiskripsikan dan dianalisis dengan menggunakan SPSS 20. Sesuai dengan rumusan masalah dan tujuan penelitian, secara hipotesis, diidentifikasikan variabel yang akan diteliti, yaitu : Pendidikan dan PAD (Pendapatan Asli Daerah) Kabupaten Lamongan.

\section{HASIL PENELITIAN DAN PEMBAHASAN \\ Pendidikan}

Tabel 1.

Jumlah Penduduk Usia Diatas 15

Tahun Yang Bisa Membaca Menulis Indikator Pendidikan Tahun 20102014

\begin{tabular}{|c|c|}
\hline Tahun & Melek huruf (ribuan) \\
\hline 2010 & 796300 \\
\hline 2011 & 817460 \\
\hline 2012 & 813568 \\
\hline 2013 & 818216 \\
\hline 2014 & 649109 \\
\hline
\end{tabular}

Sumber: BPS di Kabupaten Lamongan

\section{Pendapatan Asli Daerah (PAD)}

Tabel 2.

Total PAD Kabupaten Lamongan tahun $2010-2014$

\begin{tabular}{|l|l|l|}
\hline No & Tahun & Total PAD \\
\hline
\end{tabular}

\begin{tabular}{|l|l|l|}
\hline 1. & 2010 & $95.244 .807 .228,09$ \\
\hline 2. & 2011 & $99.545 .629 .500,31$ \\
\hline 3. & 2012 & $129.284 .733 .136,02$ \\
\hline 4. & 2013 & $161.087 .916 .084,90$ \\
\hline 5. & 2014 & $272.193 .207 .652,81$ \\
\hline
\end{tabular}

Sumber: Dinas Pendapatan Daerah, Dispenda Kabupaten Lamongan 2015 dan Perusahan Daerah.(diolah)

Pendapatan Asli Daerah pada tahun 2010 totalnya sebesar Rp 95.244.807.228,09 dan naik pada tahun $2011 \quad$ sebesar Rp 99.545.629.500,31. Pada tahu 2012 total PAD Kabupaten Lamongan Sebesar Rp 129.284.733.136,02 dan tahun 2013 PAD naik sebesar Rp 161.087.916.084,90 dan tahun 2014 PAD Kabupaten Lamongan Naik sebesar Rp 272.193.207.652,81.

\section{Analisis Statistik}

Tabel 3.

Hasil Perhitungan Korelasi Antara Pendidikan dengan Pendapatan Asli Daerah Di Kabupaten Lamongan

\begin{tabular}{|c|c|c|c|}
\hline \multicolumn{4}{|c|}{ Correlations } \\
\hline & & $\begin{array}{l}\text { Pendi } \\
\text { di-kan }\end{array}$ & PAD \\
\hline \multirow{2}{*}{$\begin{array}{l}\text { Pearson } \\
\text { Correlation }\end{array}$} & Pendidikan & 1,000 &,- 898 \\
\hline & PAD &,- 898 & 1,000 \\
\hline \multirow{2}{*}{$\begin{array}{l}\text { Sig. } \\
\text { (1-tailed) }\end{array}$} & Pendidikan & . &, 019 \\
\hline & PAD & 019 & \\
\hline \multirow[t]{2}{*}{$\mathrm{N}$} & Pendidikan & 5 & 5 \\
\hline & PAD & 5 & 5 \\
\hline
\end{tabular}

Sumber: BPS dan Pendapatan Asli Daerah di kabupaten Lamongan (Output SPSS 17)

Dari hasil perhitungan didapatkan angka korelasi antara Pendidikan dengan Pendapatan Asli Daerah Kabupaten Lamongan sebesar -0,898. Artinya hubungan kedua variabel tersebut sangat kuat tetapi negatif. 
Korelasi negatif menunjukan bahwa hubungan antara Pendidikan dengan Pendapatan Asli Daerah Kabupaten Lamongan tidak searah atau berlawanan.

Dari data dapat dilihat probalitas (sig) sebesar 0,019 yang lebih kecil dari 0,05, maka ada hubungan kedua variabel pendidikan dengan Pendapatan Asli Daerah Kabupaten Lamongan singnifikan.

Hal ini disebabkan karena Permasalahan-permasalahan

dikarenakan banyaknya pendidikan yang rendah yang ada di Kabupaten Lamongan sebagian besar tergolong sebagai unskilled labor atau tenaga kerja tidak terdidik. Tenaga kerja tidak terdidik adalah tenaga kerja kasar yang hanya mengandalkan tenaga saja. Contoh: kuli, buruh angkut, pembantu rumah tangga, dan sebagainya. Tingginya angka unskilled labor menunjukkan bahwa kualitas tenaga kerja di Jawa Timur masih rendah.

Berbagai upaya telah dilakukan oleh pemerintah Daerah Kabupaten Lamongan untuk bisa meningkatkan pendidikan di kabupaten Lamongan. Namun demikian menarik untuk diteliti apakah pendidikan di Kabupaten Lamongan berdampak terhadap Pendapatan Asli Daerah, Mengingat tingginya jumlah tenaga kerja yang terserap lebih banyak pada sektor informal. Sektor informal memang menawarkan peluang kerja yang lebih fleksibel dalam hal persyaratan namun lemah dalam hal jaminan keberlangsungan pekerjaan tersebut (job security). Pekerja sektor informal rentan terhadap gejolak ekonomi dan cenderung tidak menentu penghasilannya khususnya para pekerja bebas (pekerja tidak tetap) yang hanya bekerja sesekali saja dan berpindah-pindah majikan maupun jenis pekerjaannya. Pekerja sektor informal juga umumnya tidak dilindungi oleh fasilitas kesehatan, perlindungan kecelakaan, maupun jaminan pensiun.

\section{KESIMPULAN DAN SARAN \\ Kesimpulan}

1. Dari hasil perhitungan didapatkan angka korelasi antara Pendidikan dengan Pendapatan Asli Daerah Kabupaten Lamongan sebesar 0,898 . Artinya hubungan kedua variabel tersebut sangat kuat tetapi negatif. Korelasi negatif menunjukan bahwa hubungan antara Pendidikan dengan Pendapatan Asli Daerah Kabupaten Lamongan tidak searah atau berlawanan.

2. Dari data dapat dilihat probalitas (sig) sebesar 0,019 yang lebih kecil dari 0,05, maka ada hubungan kedua variabel pendidikan dengan Pendapatan Asli Daerah Kabupaten Lamongan singnifikan.

3. Permasalahan-permasalahan dikarenakan banyaknya pendidikan yang rendah yang ada di Kabupaten Lamongan sebagian besar tergolong sebagai unskilled labor atau tenaga kerja tidak terdidik.

\section{Saran}


Berdasarkan hasil pembahasan dan kesimpulan yang telah diuraikan diatas, Penulis mengajukan beberapa saran yang diharapkan dapat memberikan manfaat dalam upaya peningkatan Pendidikan terhadap PAD di Kabupaten Lamongan. sebagai berikut:

1. Upaya untuk meningkatkan hubungan pendidikan terhadap PAD mempunyai pengaruh dominan

2. Disamping itu perlu memperhatikan melalui variabel selain hubungan pendidikan terhadap PAD atau variabel lainnya.

\section{DAFTAR PUSTAKA}

Husaini. 2008. Buku Latihan SPSS Parametrik. Jakarta: PT. Elex Media Computindo.

Kuntjoro Jakti, Dorojatun,2003. Mau kemana Pembangunan Ekonomi Indonesia. Jakarta: Prenada Media.

Lipsey, Richard G dkk, 1991. Pengatar Makro Ekonomi. Edisi kedelapan, Jakarta: Erlangga.

Noerdhus dan samuelson, 2000. Ilmu Makro Ekonomi. Jakarta: Media Global Edukasi.

Nurcholis, 2007, Pendapatan Asli Daerah: 182.

Rosyidi, Suherman.2000. Pengantar Ilmu Ekonomi. Jakarta:Erlangga.

Sarwoko, 2005. Dasar-Dasar ekonometrika. Yogyakarta: Andi.
Sukirno, Sadono.1981. Pengantar Teori Makroeskonomi. Jakarta: Bima Grafika

Sukirno, Sadono.2004. Makroekonomi Teori Pengantar. Jakarta: Bima Grafika.

Suparmoko.1996. Pengantar Ekonometrika Makro. Edisi ketiga, Yogyakarta: BPFEYogyakarta.

Santoso, A. 2000. Buku Latihan SPSS Parametrik. Jakarta: PT Elex Media Computindo.

Sukirno,Sadono.1985. Ekonomi

Pembangunan Proses,

Masalah dan Dasar

Kebijaksanaan.Jakarta:

Fakultas Ekonomi UI dengan Bima Grafika.

Tarmidi,T Lepi.1992. Ekonomi Pembangunan.

Jakarta:Fakultas Ekonomi UI.

www.BPS.com

www.Wikipedia.com 